\title{
Evaluation of Zn-Rich Coatings for IMC Reaction Control in Aluminum- Magnesium Dissimilar Welds
}

DOI:

10.1016/j.matchar.2018.02.035

\section{Document Version}

Accepted author manuscript

Link to publication record in Manchester Research Explorer

\section{Citation for published version (APA):}

Wang, Y., \& Prangnell, P. (2018). Evaluation of Zn-Rich Coatings for IMC Reaction Control in AluminumMagnesium Dissimilar Welds. Materials Characterization. https://doi.org/10.1016/j.matchar.2018.02.035

\section{Published in:}

Materials Characterization

\section{Citing this paper}

Please note that where the full-text provided on Manchester Research Explorer is the Author Accepted Manuscript or Proof version this may differ from the final Published version. If citing, it is advised that you check and use the publisher's definitive version.

\section{General rights}

Copyright and moral rights for the publications made accessible in the Research Explorer are retained by the authors and/or other copyright owners and it is a condition of accessing publications that users recognise and abide by the legal requirements associated with these rights.

\section{Takedown policy}

If you believe that this document breaches copyright please refer to the University of Manchester's Takedown Procedures [http://man.ac.uk/04Y6Bo] or contact uml.scholarlycommunications@manchester.ac.uk providing relevant details, so we can investigate your claim.

\section{OPEN ACCESS}




\section{Accepted Manuscript}

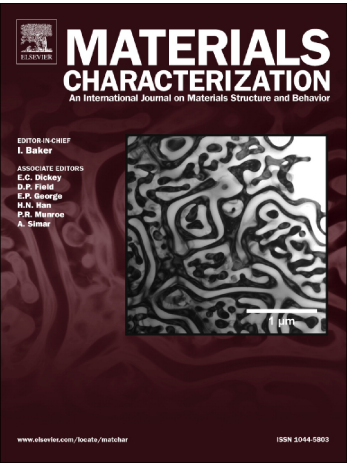

Yin Wang, Philip B. Prangnell

PII:

S1044-5803(17)33598-2

DOI: doi:10.1016/j.matchar.2018.02.035

Reference:

MTL 9079

To appear in:

Materials Characterization

Received date:

21 December 2017

Revised date:

5 February 2018

Accepted date:

23 February 2018

Please cite this article as: Yin Wang, Philip B. Prangnell, Evaluation of Zn-rich coatings for IMC reaction control in aluminum-magnesium dissimilar welds. The address for the corresponding author was captured as affiliation for all authors. Please check if appropriate. $\operatorname{Mtl}(2017)$, doi:10.1016/j.matchar.2018.02.035

This is a PDF file of an unedited manuscript that has been accepted for publication. As a service to our customers we are providing this early version of the manuscript. The manuscript will undergo copyediting, typesetting, and review of the resulting proof before it is published in its final form. Please note that during the production process errors may be discovered which could affect the content, and all legal disclaimers that apply to the journal pertain. 


\title{
Evaluation of Zn-Rich Coatings for IMC Reaction Control in Aluminum-
}

\section{Magnesium Dissimilar Welds}

\author{
Yin Wang and Philip B Prangnell* \\ School of Materials, Manchester University
}

\begin{abstract}
The dissimilar welding of $\mathrm{Al}$ to $\mathrm{Mg}$ is very challenging owing to the rapid formation of an intermetallic (IMC) reaction layer at the joint interface, typically comprised of the binary phases $\gamma-\mathrm{Al}_{12} \mathrm{Mg}_{17}$ and $\beta-\mathrm{Al}_{3} \mathrm{Mg}_{2}$. A potential metallurgical solution has been explored that aimed to change the reaction path by using Al-Zn alloy coatings to promote alternative IMCs with a slower growth rate. To determine the optimum composition for the coating, combined CALPHAD thermodynamic calculations and diffusion simulations were used to estimate the minimum $\mathrm{Zn}$ concentration (20 at.\%) required to suppress the formation of the fastest growing $\mathrm{Al}_{3} \mathrm{Mg}_{2}$ phase. This prediction was verified by both static diffusion and Refill ${ }^{\mathrm{TM}}$ friction stir spot welding (FSSW) experiments. In each case the selected coating alloy was effective in changing the Al-Mg reaction path by forming the $\tau-(\mathrm{Al}, \mathrm{Zn})_{49} \mathrm{Mg}_{32}$ phase as a substitute for $\beta-\mathrm{Al}_{3} \mathrm{Mg}_{2}$. However, in static heat treatments there was no reduction in the IMC reaction layer thickness due to the new phase having similar growth kinetics to the $\beta-\mathrm{Al}_{3} \mathrm{Mg}_{2}$ phase it replaced. Nevertheless, Refill ${ }^{\mathrm{TM}}$ friction stir spot welds prepared with the new AL-Zn coating alloy exhibited a thinner reaction layer and an increase in lap shear strength. This benefit was attributed to the $\mathrm{Zn}$ addition reducing the joint interface liquation temperature, which resulted in a lower peak weld temperature and less IMC reaction; although an increase in local eutectic melting limited the improvement observed.
\end{abstract}

Phil Prangnell

Professor in Materials Engineering

School of Materials

MSS Bldg

The University of Manchester

M13 9PL

Email: philip.prangnell@manchester.ac.uk

Tel. + 44 (0)1613063610 
Yin Wang: yinwang.manchester@gmail.com 


\section{Introduction}

Replacing steel with lower density alloys is a growing trend in the automotive industry where weight reduction is becoming an increasingly important requirement, to increase fuel efficiency and extend the range of electric vehicles [1]. It is now recognized that the most efficient vehicle designs are based on a multi-material approach, where the best attributes of different materials can be exploited in a single structure. This multi-material design philosophy has increased interest in joining dissimilar automotive alloys. However, it has been found to be very challenging to directly join $\mathrm{Al}$ to $\mathrm{Mg}$, even when using lower temperature solid-state welding techniques such as friction stir welding (FSW). [2-7].

The main issue in welding $\mathrm{Al}$ to $\mathrm{Mg}$ alloys is the rapid formation of intermetallic compounds (IMCs) at the weld interface, which embrittles the joints and makes them unusable for safety critical applications [2-7]. Rapid IMC reaction occurs in this system owing to the high diffusivities of Al and $\mathrm{Mg}$ in each weld member and, perhaps unusually, through the IMC phases themselves which often form a continuous barrier layer at the weld interface [7-12]. For example, the activation energy for interdiffusion in binary Al-Mg IMCs have been reported to be much less than for Al-Fe intermetallic phases (e.g. $\sim 870 \mathrm{~kJ} / \mathrm{mol}$ for the $\beta-\mathrm{Al}_{3} \mathrm{Mg}_{2}$ phase and $\sim 200 \mathrm{~kJ} / \mathrm{mol}$ for $\mathrm{Fe}_{2} \mathrm{Al}_{5}[7-10$, $13,14]$. There are three main IMCs that can form in $\mathrm{Al}-\mathrm{Mg}$ diffusion couples, namely $\gamma-\mathrm{Al}_{12} \mathrm{Mg}_{17}$, $\beta-\mathrm{Al}_{3} \mathrm{Mg}_{2}$, and $\varepsilon-\mathrm{Al}_{30} \mathrm{Mg}_{23}$ [7, 15-17]. Of these phases, $\varepsilon-\mathrm{Al}_{30} \mathrm{Mg}_{23}$ has sluggish kinetics and is not normally seen in welding $[7,17,18]$ and $\beta-\mathrm{Al}_{3} \mathrm{Mg}_{2}$ is regarded as having the greatest impact on compromising the mechanical performance of welded joints, because it has the highest growth rate and generally forms the dominant IMC layer at the weld interface [7,8,9,12]. Interfacial cracking also preferentially occurs within this phase, owing to its greater thickness, poor mechanical properties and large residual stresses [7, 19]. Therefore, in principle by taking measures to control the formation of the $\beta-\mathrm{Al}_{3} \mathrm{Mg}_{2}$ phase the performance of $\mathrm{Al}-\mathrm{Mg}$ dissimilar welds could be improved.

A metallurgical approach explored in this paper to attaining this goal is to develop an interlayer for $\mathrm{Al}-\mathrm{Mg}$ joints with a composition that promotes a new reaction path and, thereby, suppresses the formation of the undesirable $\beta-\mathrm{Al}_{3} \mathrm{Mg}_{2}$ phase. To be practical in a friction welding process this 
would be simplest to achieve through the application of a coating to the surface of one of the weld members. However, the survivability of the coating also needs to be taken into consideration, when selecting an appropriate material, as in a previous attempt by the current authors it has been found that thin brittle barrier coatings (e.g. PVD Mn) break up during friction welding, compromising their effectiveness [20].

There have been several studies showing that a $\mathrm{Zn}$-rich interlayer, either existing in the form of a pure $\mathrm{Zn}$ foil [21,22] or as an Al-Zn alloy [23,24], can enhance the mechanical properties of $\mathrm{Al}-\mathrm{Mg}$ dissimilar joints. For example, the shear strength of $\mathrm{Al}-\mathrm{Mg}$ diffusion bonds has been claimed to double when using an Al-Zn alloy interlayer [23]. In this research, Zn rich interlayers have been reported to be effective in inhibiting the production of $\mathrm{Al}-\mathrm{Mg}$ binary IMCs at the weld interface, by substituting them with $\mathrm{Mg}-\mathrm{Zn}$ binary and Al-Mg-Zn ternary phases, which were claimed to have slower growth kinetics [23]. Suppression of the formation of the binary Al-Mg IMCs was proposed by the authors $[23,24]$ as the main mechanism that led to an improved joint performance. However, although $\mathrm{Zn}$-rich interlayers show promise for reducing the problem of rapid IMC reaction in dissimilar joining $\mathrm{Al}$ to $\mathrm{Mg}$, important aspects of this approach remain unknown, including the optimum $\mathrm{Zn}$ composition, and a full assessment of the phases formed and their growth kinetics under controlled conditions, as well as the properties of the new IMCs formed.

The aim of this work was therefore to more systematically study the potential for Zn-rich coatings to reduce the detrimental effects of intermetallic phase reactions during solid state welding of $\mathrm{Al}$ to $\mathrm{Mg}$ automotive alloys. To obtain a coating interlayer with sufficient ductility to survive friction welding, an $\mathrm{Al}-\mathrm{Zn}$ alloy was selected and thermodynamic calculations and interdiffusion simulations were first used to 'design' the ideal composition. The compositions selected were then initially investigated in inter-diffusion experiments using static heat treatments, in order to compare their effectiveness under accurately controlled temperatures and to produce samples that allowed the mechanical properties of the individual phases to be compared using nanoindentation tests. The optimized composition was then friction stir spot welded to a $\mathrm{Mg}$ alloy to test its performance under more transient welding conditions. In addition, the intermetallic phases formed between the Al- $\mathrm{Zn}$ interlayers and $\mathrm{Mg}$ have been fully characterized and compared to the conventional binary IMC phases seen in $\mathrm{Al}-\mathrm{Mg}$ dissimilar joints. 


\section{Methodology}

\subsection{Modelling}

To identify weld interlayer alloy compositions of interest, the CALPHAD software tool PANDAT ${ }^{\mathrm{TM}}$ and the latest aluminium database diagram was first used to calculated $\mathrm{Al}-\mathrm{Mg}-\mathrm{Zn}$ ternary phase diagram. A one dimensional diffusion simulation was then employed, using the computational tool DICTRA $^{\mathrm{TM}}$, to predict the development of the composition profile in $\mathrm{Al}-\mathrm{Zn}-\mathrm{Mg}$ couples with different initial $\mathrm{Zn}$ concentrations. In the calculations the $\mathrm{Mg}$ alloy starting composition was fixed to be that of the commercial alloy AZ31 (Table 1), which is widely employed in the automotive industry (the same alloy was also used for experimental verification). As the required diffusion coefficients in all the relevant IMC phases are not known, for simplicity, a single-phase model was used in the calculations, which assumed that the diffusion couple remains as an $\mathrm{Al}$ and $\mathrm{Mg}$ solid solution. For each starting composition, the concentration profiles of all three elements were then calculated after various inter-diffusion periods (up to 24 hours at $360{ }^{\circ} \mathrm{C}$ ). By plotting the locus of the compositions predicted by DICTRA on the ternary phase diagram (Fig. 1a), a diffusion profile was then obtained that could be related to the equilibrium phase stabilities at each specific composition (Fig. 1b).

\subsection{Experimental}

To validate the modelling predictions, reaction with Al-Zn coating alloys of the desired composition was simulated by casting small book molds and rolling them to the same $1 \mathrm{~mm}$ thickness as the baseline standard sheet materials. These samples were subsequently used for the isothermal inter-diffusion experiments and observation of the interfacial reaction after FSSW. The Mg alloy, AZ31, was used for preparing all the dissimilar joints (Table 1). Three Al-Zn compositions were selected based on the diffusion simulations. The alloys were cast using $\mathrm{Al}$ and $\mathrm{Zn}$ with a purity of $99.9 \%$. The ingots were then hot rolled to $1 \mathrm{~mm}$ thick sheet, homogenised at $460{ }^{\circ} \mathrm{C}$, and quenched in water to obtain supersaturated Al-Zn solid solutions. The conventional Al automotive alloy AA6111 (Table 1) was also used to prepare Al - Mg baseline samples for comparison purposes, 
with the same AZ31 alloy.

For static heat treatment experiments, the sheets were cut into $30 \mathrm{~mm} \times 30 \mathrm{~mm}$ squares, and deoxidized by grinding with 320-grit sandpaper and washing in ethanol. To obtain a metallurgical bond prior to heat treatment, the $\mathrm{Al}$ and $\mathrm{Mg}$ samples were first lightly welded together using a $2 \mathrm{~kW}$ Sonobond ultrasonic spot welder with a very short dwell time of 0.2 seconds. The samples were then held at $360{ }^{\circ} \mathrm{C}$ in a furnace for different times, to study the microstructural evolution at the joint interfaces. For the welding experiments, the sheet materials were cut into $25 \mathrm{~mm} \times 100 \mathrm{~mm}$ coupons and treated using the same surface cleaning procedure. The Refill ${ }^{\mathrm{TM}}$ FSSW technique [25] was adopted to produce the dissimilar joints, using optimized parameters previously developed by the current authors [26, 27] consisting of a rotation rate of $2000 \mathrm{rpm}$, sleeve plunge depth of $1 \mathrm{~mm}$, and a welding duration of $1 \mathrm{sec}$.). During welding the AZ31 Mg alloy sheet was placed on the top of the lap joint and both materials were aligned in the rolling direction (RD).

Microstructural analysis was performed on the dissimilar joints sectioned perpendicular to the rolling direction $(\mathrm{RD})$ in the ND-TD plane (normal - transverse direction) after metallographic preparation using water free, oil-based, diamond paste and a silica particle suspension. BSE and electron EBSD analysis were carried out on an FEI Magellan HR FEG-SEM equipped with EBSD and EDX detectors. TEM samples of the interface region were prepared using focused ion beam (FIB) milling with an FEI Quanta 3D FIB machine. Analysis was conducted in an FEI Tecnai G2 20 TEM equipped with an EDX detector.

The hardness and elastic moduli of the IMC interface phases formed in the heat treated samples were evaluated using a nano-indentation technique. A Berkovich indentor tip was used for the measurements. A matrix of $8 \times 3$ indents with a $5 \mu$ m separation was made across the intermetallic layers. In addition, lap shear tests were carried out using an Instron testing machine at a loading rate of $1 \mathrm{~mm} / \mathrm{min}$, to characterize the effectiveness of the coating material on increasing the joint strength of the dissimilar welds. The interface temperature during FSSW was measured using 0.5 mm k-type thermocouples placed directly under the sleeve position of the welding tool, which is known to be the hottest weld location [26 -28]. The peak interface temperatures reached were 
averaged from three measurements obtained for each material combination.

Table 1 Compositions of the materials investigated, (wt. \%).

\begin{tabular}{|c|c|c|c|c|c|c|c|}
\hline & $\mathrm{Al}$ & $\mathrm{Si}$ & $\mathrm{Zn}$ & $\mathrm{Fe}$ & $\mathrm{Cu}$ & $\mathrm{Mn}$ & $\mathrm{Mg}$ \\
\hline AA6111 & Balance & $0.6-1.1$ & $<0.15$ & $<0.4$ & $0.5-0.9$ & $0.1-0.45$ & $0.5-1$ \\
\hline AZ31 & $2.5-3.5$ & $<0.1$ & $0.7-1.3$ & - & & $0.2-0$ & Balance \\
\hline $10 \% \mathrm{Zn}$ & Balance & $<0.0 .1$ & 4.4 & $<0.1$ & & - & - \\
\hline $20 \% \mathrm{Zn}$ & Balance & $<0.0 .1$ & 9.4 & & $<0.03$ & - & - \\
\hline $30 \% \mathrm{Zn}$ & Balance & $<0.0 .1$ & 15 & $<0$ & $<0.03$ & - & - \\
\hline
\end{tabular}

\section{Results and Discussion}

\subsection{Coating Design}

The combined thermodynamic and inter-diffusion calculations described above were first used to predict the optimum composition of an $\mathrm{Al}-\mathrm{Zn}$ rich coating alloy that would be required to prevent production of the $\beta-\mathrm{Al}_{3} \mathrm{Mg}_{2}$ phase during dissimilar welding of an $\mathrm{Al}-\mathrm{Zn}$ interlayer alloy to Mg-AZ31. Fig. 1(a) shows an isothermal section of the ternary system at $360^{\circ} \mathrm{C}$, which is at the lower end of the typical range of peak temperatures measured during friction stir spot welding of $\mathrm{Al}$ to $\mathrm{Mg}$ (e.g. $360{ }^{\circ} \mathrm{C}$ to $437{ }^{\circ} \mathrm{C}$ ) where the upper limit corresponds to the eutectic temperature for the reaction $\mathrm{Mg}+\gamma-\mathrm{Al}_{12} \mathrm{Mg}_{17} \rightarrow$ Liq. [15, 16, 29]. According to the calculations, and other thermodynamic assessments (e.g. [30]), there are several binary and ternary IMCs thermodynamically stable at this temperature, namely the $\mathrm{Al}-\mathrm{Mg}$ binary phases $\beta-\mathrm{Al}_{3} \mathrm{Mg}_{2}$, $\gamma-\mathrm{Al}_{12} \mathrm{Mg}_{17}$ and $\varepsilon-\mathrm{Al}_{30} \mathrm{Mg}_{23}$, the $\mathrm{Mg}-\mathrm{Zn}$ binary phases $\mathrm{Mg}_{2} \mathrm{Zn}_{3}, \mathrm{MgZn}_{2}$ and $\mathrm{Mg}_{2} \mathrm{Zn}_{11}$, and the Al-Mg-Zn ternary phases $\tau-(\mathrm{Al}, \mathrm{Zn})_{49} \mathrm{Mg}_{32}$ and $\phi-\mathrm{Al}_{4} \mathrm{Mg}_{2} \mathrm{Zn}_{3}$. From Fig. 1 (a) it can be seen that to 
eliminate the rapidly growing $\beta-\mathrm{Al}_{3} \mathrm{Mg}_{2}$ phase the composition at the weld interface needs to be kept outside the composition range shaded in grey, where the undesired $\beta-\mathrm{Al}_{3} \mathrm{Mg}_{2}$ phase is stable.

Diffusion profiles for three example alloys with $10 \%, 20 \%$, and $30 \% \mathrm{Zn}$ concentrations have been plotted on the ternary phase diagram shown in Fig. 1(a). For the simulation with the lowest $\mathrm{Zn}$ concentration alloy (Al-10\% $\mathrm{Zn}$ ) it can be seen that the composition profile passes through the undesirable $\beta-\mathrm{Al}_{3} \mathrm{Mg}_{2}$ phase field, while the profile for the couple with the highest $\mathrm{Zn}$ content alloy of $30 \%$ predicts that $\beta-\mathrm{Al}_{3} \mathrm{Mg}_{2}$ will be completely eliminated and replaced by the ternary phase $(\mathrm{Al}, \mathrm{Zn})_{49} \mathrm{Mg}_{32}$. In comparison, the curve for the $20 \% \mathrm{Zn}$ couple just touches the tip of the grey-shaded phase field in which $\beta-\mathrm{Al}_{3} \mathrm{Mg}_{2}$ is stable and thermodynamically this, therefore, represents the minimum $\mathrm{Zn}$ content required to avoid the formation of the $\beta-\mathrm{Al}_{3} \mathrm{Mg}_{2}$ phase at typical welding temperatures.

From considering all the phase fields though which the $\mathrm{Al}-20 \% \mathrm{Zn}-\mathrm{Mg}$ diffusion profile passes, several alternative intermetallic phases could potentially form at this temperature; namely $\mathrm{Mg}_{2} \mathrm{Zn}_{3}$, $\tau$-(Al,Zn) ${ }_{49} \mathrm{Mg}_{32}, \gamma-\mathrm{Al}_{12} \mathrm{Mg}_{17}$ and $\phi-\mathrm{Al}_{4} \mathrm{Mg}_{2} \mathrm{Zn}_{3}$. This inference is also supported by Fig. 1(b), which compares the calculated energies of formation of all the possible phases across the Al-20\% $\mathrm{Zn}-$ Mg diffusion profile in Fig. 1(a). Form Fig. 1(b) it can be seen that from approximately 20 at. \% to 45 at. $\% \mathrm{Mg}$, the $\tau$-(Al, $\mathrm{Zn})_{49} \mathrm{Mg}_{32}$ phase exhibits the lowest Gibbs free energy, and should thus potentially substitute for the undesirable $\beta-\mathrm{Al}_{3} \mathrm{Mg}_{2}$ phase. However, this figure also shows that the $\tau-(\mathrm{Al}, \mathrm{Zn})_{49} \mathrm{Mg}_{32}, \quad \varepsilon-\mathrm{Al}_{30} \mathrm{Mg}_{23}$ and $\gamma-\mathrm{Al}_{12} \mathrm{Mg}_{17}$ phases have formation energies very close to one another in the compositional range from about 45 at. $\%$ to 50 at. $\% \mathrm{Mg}$, which indicates they all have similar potential to appear at the $\mathrm{Mg}$ side of an $\mathrm{Al}-20 \% \mathrm{Zn}-\mathrm{Mg}$ interdiffusion layer. 


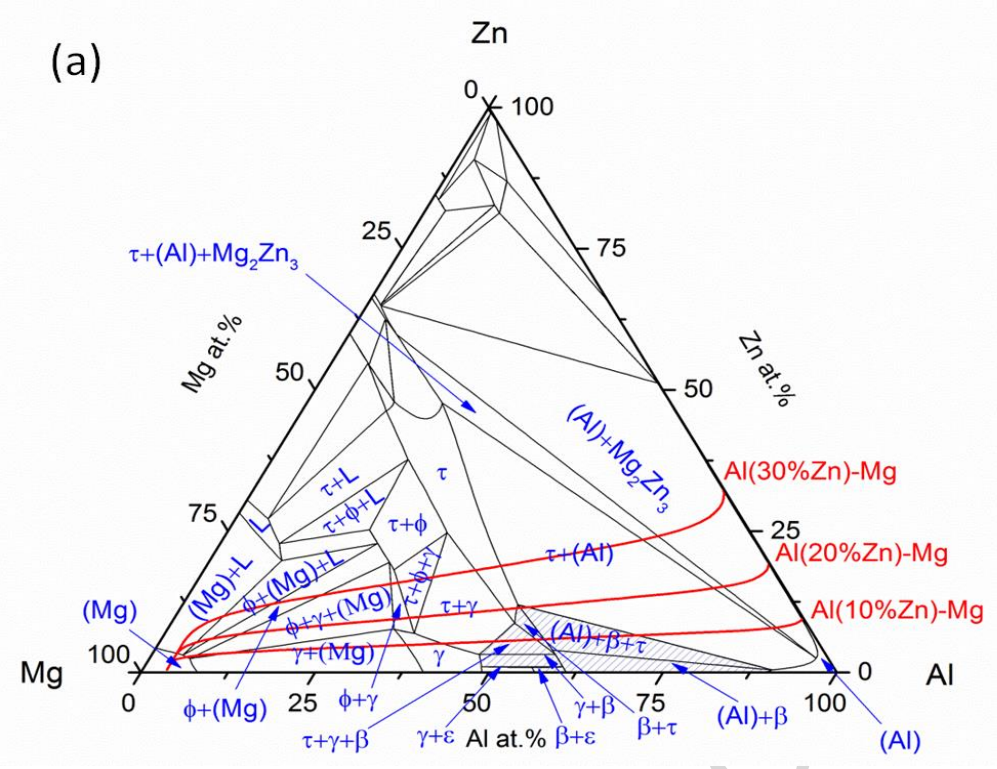

(b)

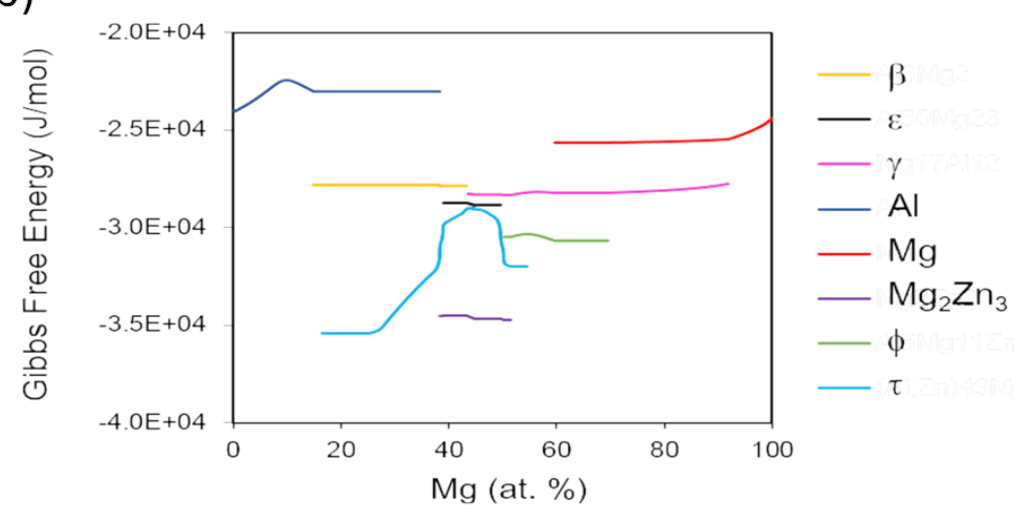

Fig. 1 Examples of Al-Mg-Zn equilibrium and diffusion calculations; (a) an isothermal section calculated at $360^{\circ} \mathrm{C}$ with the simulated diffusion profiles marked in red; (b) the Gibbs free energies of all the phases along the Al-20\% $\mathrm{Zn}-\mathrm{Mg}$ profile shown in (a).

It should be noted that although the above thermodynamic-based simulations predict that an interlayer alloy with a composition of $\mathrm{Al}-20$ at. \% $\mathrm{Zn}$ will be the minimum $\mathrm{Zn}$ content required to avoid the rapidly growing $\beta-\mathrm{Al}_{3} \mathrm{Mg}_{2}$ phase, when welding in the temperature range of $360-437{ }^{\circ} \mathrm{C}$, in practise whether a phase will actually appear also depends on kinetic considerations. Hence, to validate the predictions, results are reported in the following sections where interlayer coating alloys with the same compositions were tested under static heat treatment and welding conditions. 


\subsection{Static Diffusion Experiments}

Fig. 2 compares the typical interfacial microstructure of the $\mathrm{Al}-\mathrm{Mg}$ baseline interdiffusion sample (AA6111 to AZ31) with that of the equivalent Al-20\% Zn - Mg couple, which had the minimum predicted $\mathrm{Zn}$ composition to avoid the $\beta-\mathrm{Al}_{3} \mathrm{Mg}_{2}$ phase field, following static annealing at $360{ }^{\circ} \mathrm{C}$ for $24 \mathrm{hrs}$. In the $\mathrm{Al}-\mathrm{Mg}$ baseline sample three intermetallic layers can be observed at the joint interface (Fig. 2a and b). The two thicker layers immediately adjacent to the $\mathrm{Mg}$ and $\mathrm{Al}$ sides of the weld were identified to be the $\gamma-\mathrm{Al}_{12} \mathrm{Mg}_{17}$ and $\beta-\mathrm{Al}_{3} \mathrm{Mg}_{2}$ phases, respectively, as has been reported in previous studies (e.g., [7, 12, 18,]). The third, thinner, mid-layer, which has not been commonly observed, was indexed to be the $\varepsilon-\mathrm{Al}_{30} \mathrm{Mg}_{23}$ phase by selected area diffraction as shown in Fig. $2 \mathrm{c}$ (a further TEM image of the $\varepsilon\left(\mathrm{Al}_{30} \mathrm{Mg}_{23}\right)$ phase and diffraction date is shown in Fig. 3). This phase is also disused in a recently published companion paper by the current authors [7]. Of the three IMCs observed, the $\beta-\mathrm{Al}_{3} \mathrm{Mg}_{2}$ phase can be seen to have developed to be the thickest layer as it has the highest growth rate, although it forms shortly after $\gamma-\mathrm{Al}_{12} \mathrm{Mg}_{17}$, whereas the $\varepsilon-\mathrm{Al}_{30} \mathrm{Mg}_{23}$ phase only develops after prolonged heat treatment and is not normally seen in dissimilar welds [7].

In the $\mathrm{Al}-20 \% \mathrm{Zn}$ - Mg sample, after the same heat treatment a similar three-layer IMC structure was observed (Fig. 2d). However, EDX measurements across the interface indicated that the individual layers were composed of different compounds, as plateaus with different stoichiometry's appeared in the composition profiles (Fig. 2e). In addition, Zn was found in all three of the IMC layers and increased in concentration discontinuously towards the Al-Zn substrate. In the thickest layer, that formed adjacent to the Al-Zn side of the diffusion couple, an average composition of $\mathrm{Al}_{45} \mathrm{Mg}_{40} \mathrm{Zn}_{15}$ was measured, which is consistent with that of the $\tau-(\mathrm{Al}, \mathrm{Zn})_{49} \mathrm{Mg}_{32}$ phase (typically about 40 at. $\% \mathrm{Mg}$, with a range of $\mathrm{Al}$ to $\mathrm{Zn}[31,32])$. This phase formed near the $\mathrm{Al}$ substrate where the $\beta-\mathrm{Al}_{3} \mathrm{Mg}_{2}$ phase is usually seen in an $\mathrm{Al}-\mathrm{Mg}$ binary couple and in this sample no $\beta-\mathrm{Al}_{3} \mathrm{Mg}_{2}$ was found, confirming the thermodynamic predictions presented above (Fig. 1). 

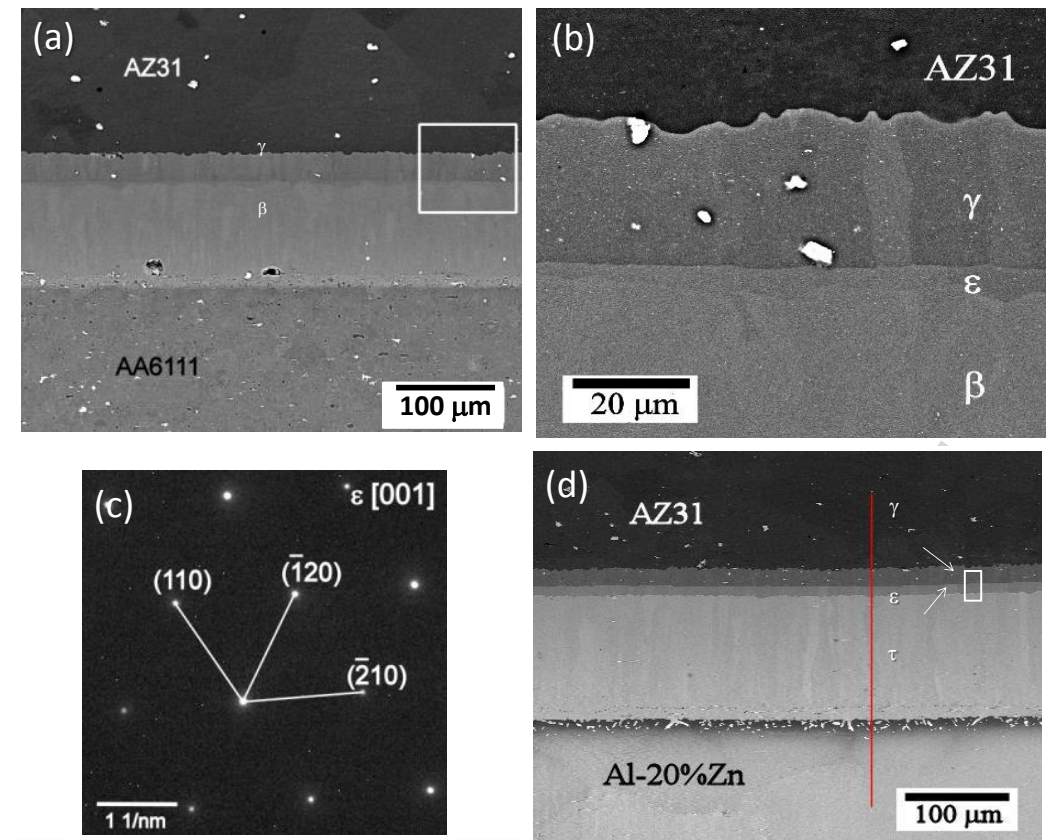

(e)

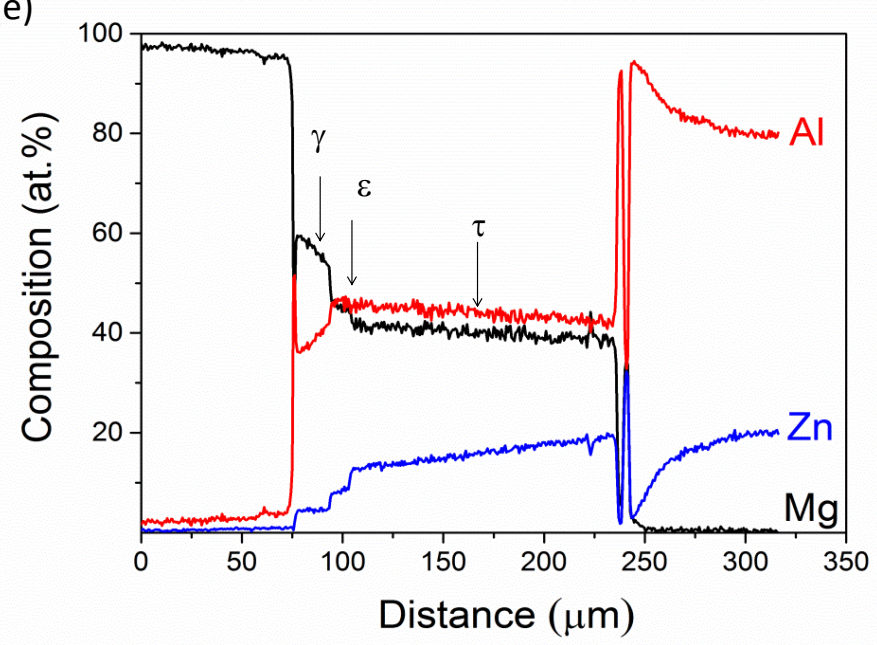

Fig. 2 Interfacial microstructures from the $\mathrm{Al}-\mathrm{Mg}$ and $\mathrm{Al}-20 \% \mathrm{Zn}-\mathrm{Mg}$ dissimilar diffusion couples, compared after static annealing at $360{ }^{\circ} \mathrm{C}$ for 24 hrs: (a) BSE micrograph of the interface region in the $\mathrm{Al}$ - Mg sample; (b) higher magnification view from the white box area in (a); (c) a TEM SAD pattern of the $\varepsilon-\mathrm{Al}_{30} \mathrm{Mg}_{23}$ phase; (d) BSE micrograph of the interface region in the Al-20 \% Zn - Mg couple; (e) EDX line scan profile along the red line in (d).

To more rigorously identify the phases found in the Al-20\% $\mathrm{Zn}-\mathrm{Mg}$ (AZ31) sample, TEM analysis was conducted on a FIB specimen extracted from the central region of the interface (white box in Fig. 2d), and the results are illustrated in Fig. 3. Fig. 3(a) shows the FIB foil, in which the 
three intermetallic layers (i., ii. and iii.) can be seen. The step change in their compositions' was further confirmed by EDX STEM analysis along the red line (Fig. 3b). Selected area diffraction (SAD) patterns of the two IMC layers closest to the $\mathrm{Mg}$ side of the joint (layer i. and ii.) were indexed to match the $\mathrm{Al}-\mathrm{Mg}$ binary $\gamma-\mathrm{Al}_{12} \mathrm{Mg}_{17}$ and $\varepsilon-\mathrm{Al}_{30} \mathrm{Mg}_{23}$ phases, respectively (Fig. $3 \mathrm{c}$ and d). This means that the significant $\mathrm{Zn}$ concentrations measured in these two phases were from solute atoms. $\mathrm{Zn}$ is known to substitute for $\mathrm{Al}$ in these phases and in the ternary system they should actually be referred to as the $\gamma-(\mathrm{Al}, \mathrm{Zn})_{12} \mathrm{Mg}_{17}$ and $\varepsilon-(\mathrm{Al}, \mathrm{Zn})_{30} \mathrm{Mg}_{23}$ [33].

Diffraction patterns from the third layer (iii. in Fig. 3) adjacent to the Al side of the joint gave good agreement with that of the $\tau-(\mathrm{Al}, \mathrm{Zn})_{49} \mathrm{Mg}_{32}$ phase. For example, Fig. $3 \mathrm{e}$ has been indexed as the [012] zone for this crystal structure [31,34]. Based on the selected area diffraction data and the EDX compositional analysis, it thus seems safe to conclude that the $\tau-(\mathrm{Al}, \mathrm{Zn})_{49} \mathrm{Mg}_{32}$ phase formed adjacent to the $\mathrm{Al}-\mathrm{Zn}$ alloy interface during static annealing, replacing the $\beta-\mathrm{Al}_{3} \mathrm{Mg}_{2}$ phase which was not detected. Hence, at this heat treatment temperature the experimental results confirm the thermodynamic predictions that a composition of $\mathrm{Al}-20 \% \mathrm{Zn}$ is effective in eliminating the binary $\beta$ phase and replacing it with the ternary compound $\tau-(\mathrm{Al}, \mathrm{Zn})_{49} \mathrm{Mg}_{32}$. 

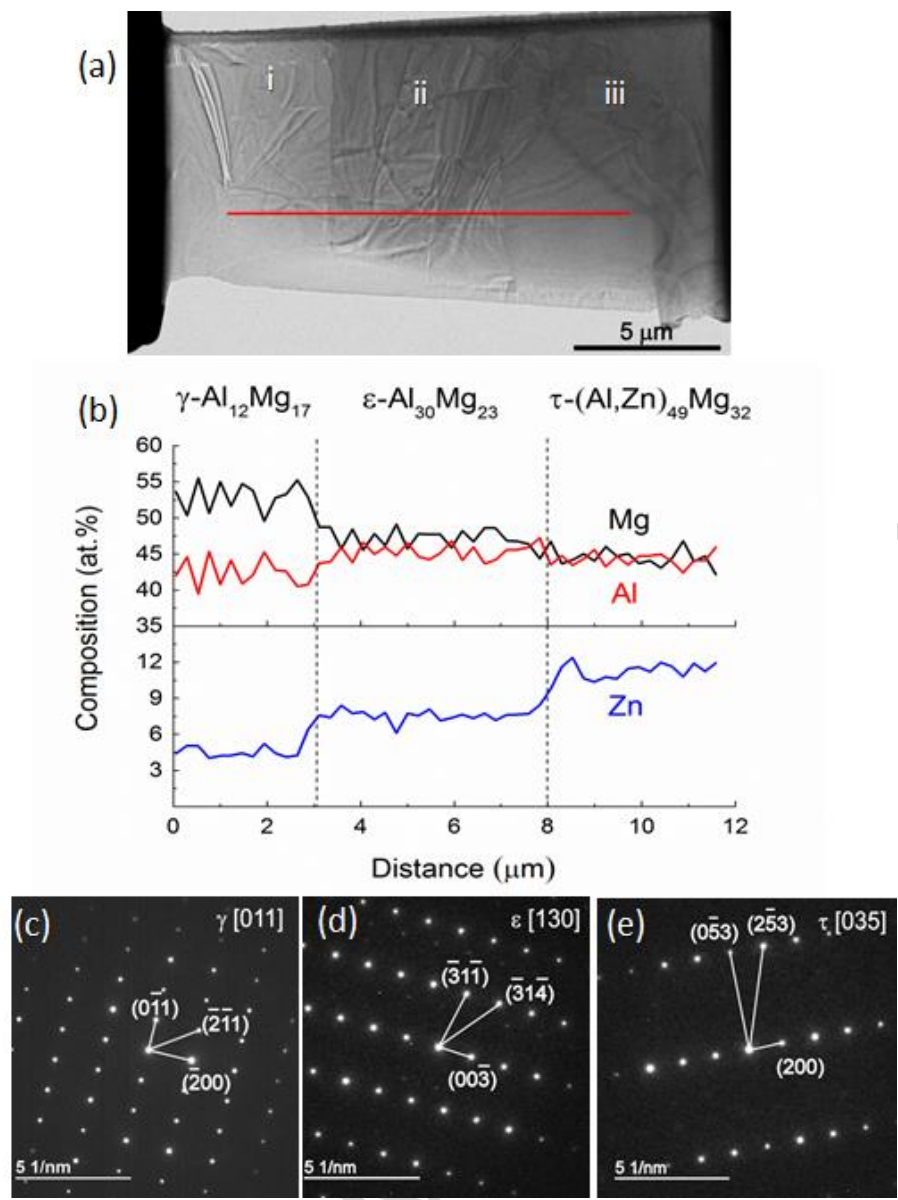

Fig. 3 TEM characterization of IMCs seen in the Al-20\% Zn - Mg diffusion couple, after heat treatment at $360^{\circ} \mathrm{C}$ for 24 hours; (a) the area of interest prepared by FIB milling; (b) EDX line scan profiles collected along the red line in (a); (c)-(e) diffraction patterns from layers A, B and C, indexed as $\gamma-\mathrm{Al}_{12} \mathrm{Mg}_{17}, \varepsilon-\mathrm{Al}_{30} \mathrm{Mg}_{23}$ and $\tau-(\mathrm{Al}, \mathrm{Zn})_{49} \mathrm{Mg}_{32}$ phase, respectively.

The two additional experimental alloys with lower (10\%) and higher (30\%) Zn contents were also USW bonded to the AZ31 Mg alloy and heat treated, in order to further assess the validity of the inter-diffusion predictions. Their interfacial regions are compared to that of the $20 \% \mathrm{Zn}$ alloy in Fig. 4, after heat treatment at $360{ }^{\circ} \mathrm{C}$ for three hours. It can be seen that all three samples exhibit an interfacial structure comprised of three intermetallic layers, with the upper layer being $\gamma-\mathrm{Al}_{12} \mathrm{Mg}_{17}$ and the middle $\varepsilon-\mathrm{Al}_{30} \mathrm{Mg}_{23}$. However, in the lower $\mathrm{Zn}$ content $\mathrm{Al}-10 \% \mathrm{Zn}-\mathrm{Mg}$ sample, the dominant lower layer can be seen to be composed of two phases that grew collaboratively as an alternating co-columnar structure. EDX analysis parallel to the interface plane (along the red line in Fig. 4a) indicated that this layer was comprised of a mixture of $\beta-\mathrm{Al}_{3} \mathrm{Mg}_{2}$ and $\tau-(\mathrm{Al}, \mathrm{Zn})_{49} \mathrm{Mg}_{32}(\mathrm{Fig}$. $4 d)$. This observation is again in good agreement with the simulation result that predicted that a lower $\mathrm{Zn}$ content would be insufficient to fully suppress the formation of the undesirable $\beta$ phase 
and the diffusion path should cross the $\beta-\mathrm{Al}_{3} \mathrm{Mg}_{2}$ and $\tau-(\mathrm{Al}, \mathrm{Zn})_{49} \mathrm{Mg}_{32}$ phase field (Fig. 1b). However, similar to in the $\mathrm{Al}-20 \% \mathrm{Zn}-\mathrm{Mg}$ diffusion couple, the dominant reaction layer in the higher $\mathrm{Zn}$ content Al-30 \% $\mathrm{Zn}-\mathrm{Mg}$ sample was found to be composed of a single $\tau$-(Al, $\mathrm{Zn})_{49} \mathrm{Mg}_{32}$ phase, with no $\beta-\mathrm{Al}_{3} \mathrm{Mg}_{2}$ detected. These results therefore confirm the predictions from the simplified diffusion simulations, that at typical FSW welding temperatures the $\beta-\mathrm{Al}_{3} \mathrm{Mg}_{2}$ phase field can be avoided with a $\mathrm{Zn}$ content above 20 at.\%. Finally, in all samples a thin microstructurally distinct continuous $\tau$ phase layer could be seen adjacent to the Al coating alloy, with a finer grain structure where it has a grown in to the substrate alloy. This behavior is discussed further in reference [7] and is associated with the formation of some Kirkendall voids and the concentration of constituent particles present in the substrate material. 

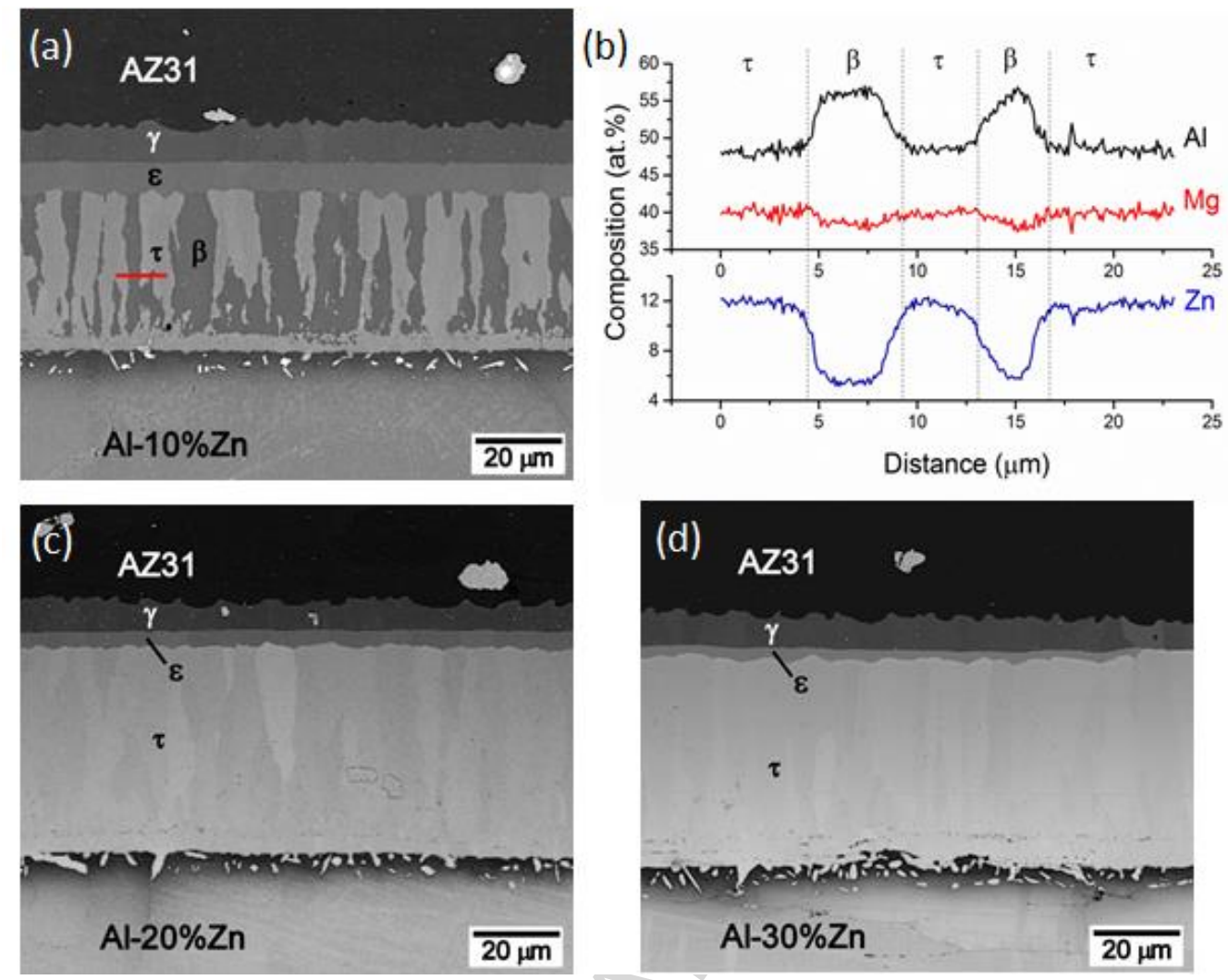

Fig. 4 SEM-BSE images comparing the interfacial IMC reaction layer in the static $\mathrm{Al}(\mathrm{Zn})-\mathrm{Mg}$ heat treated samples after $360{ }^{\circ} \mathrm{C}$ for 3 hours; (a) with $10 \% \mathrm{Zn}$ showing a dual phase columnar IMC layer and (b) an accompanying EDX profile along the line in (a) and (c) and (d) with 20\% and $30 \%$ $\mathrm{Zn}$ respectively.

\subsection{IMC Layer Growth Rates}

Fig. 5 provides a quantitative description of the growth rates of the IMC layers during isothermal heat treatment at $360{ }^{\circ} \mathrm{C}$. The thicknesses of the individual IMC phases $\left(\gamma-\mathrm{Al}_{12} \mathrm{Mg}_{17}, \beta-\mathrm{Al}_{3} \mathrm{Mg}_{2}\right.$ and $\tau$-(Al, $\left.\mathrm{Zn})_{49} \mathrm{Mg}_{32}\right)$, as well as that of the total IMC layer, are compared as a function time for samples produced with the two higher Zn level interlayer alloys and with the baseline $\mathrm{Al}(6111)$ alloy $\operatorname{Mg}(\mathrm{AZ3})$ sample. It can been noted in Fig. 5a that, despite changing the dominant IMC phase formed, the two Al- $\mathrm{Zn}$ - Mg samples exhibited a remarkably similar overall thickening rate to that of the baseline sample, indicating that the high $\mathrm{Zn}$ content inter-layer alloys had surprisingly little effect on the overall IMC reaction layer growth rate at this temperature. In addition, from comparison of the $\mathrm{Al}-\mathrm{Zn}-\mathrm{Mg}$ and $\mathrm{Al}-\mathrm{Mg}$ samples it can be seen that, contrary to expectation [23, 
$24]$, the ternary $\tau-(\mathrm{Al}, \mathrm{Zn})_{49} \mathrm{Mg}_{32}$ phase actually grew at a slightly faster rate than the $\beta-\mathrm{Al}_{3} \mathrm{Mg}_{2}$ phase it replaced (Fig. 5c), although the addition of $\mathrm{Zn}$ significantly retarded the thickening rate of the $\gamma-\mathrm{Al}_{12} \mathrm{Mg}_{17}$ phase (Fig. 5b). Overall, this resulted in the total thickness of the IMC layer in the $\mathrm{Al}-\mathrm{Zn}$ - Mg samples slightly exceeding that of the $\mathrm{Al}(6111)$ - Mg joints (Fig. 5a). Consequently, in contrast to previous reports $[23,24]$ of their respective IMC growth kinetics, under controlled conditions the $\mathrm{Al}-\mathrm{Zn}$ interlayer alloys were not found to be beneficial in inhibiting the thickening rate of the overall IMC reaction layer in an Al- Mg diffusion couple. 

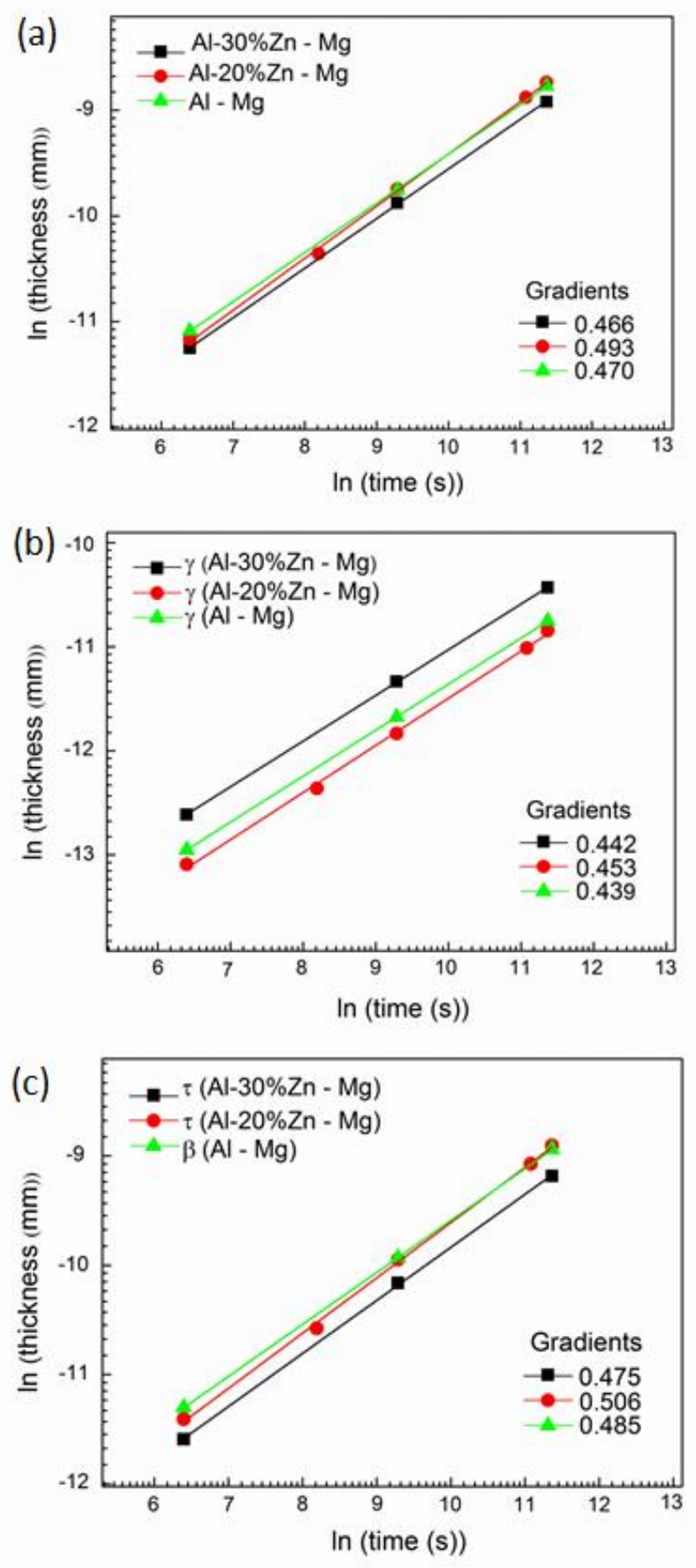

Fig. 5 Comparison of IMC layer growth rates for the $\mathrm{Al}-\mathrm{Mg}, \mathrm{Al}-20 \% \mathrm{Zn}-\mathrm{Mg}$ and $\mathrm{Al}-30 \% \mathrm{Zn}-$ $\mathrm{Mg}$ samples during isothermal heat treatment at $360{ }^{\circ} \mathrm{C}$; (a) the entire IMC layer; (b) the $\gamma-\mathrm{Al}_{12} \mathrm{Mg}_{17}$ phase; and (c) the $\tau-(\mathrm{Al}, \mathrm{Zn})_{49} \mathrm{Mg}_{32}$ and $\beta-\mathrm{Al}_{3} \mathrm{Mg}_{2}$ phases. 


\subsection{Mechanical Properties of the IMC Phases}

Intermetallic compounds produced by inter-diffusion at a bi-metallic interface usually form a weak link in dissimilar metal welds; hence, a full understanding of their mechanical properties is important if dissimilar joints are to be optimized. Fig. 6 shows the hardness and elastic moduli of the intermetallic phases found in the $\mathrm{Al}-20 \% \mathrm{Zn}-\mathrm{Mg}$ sample after heat treatment measured from nano-indentation load - displacement curves. Results for the $\mathrm{Al}$ - Mg baseline sample are also provided for comparison [7]. It can be seen that the addition of $\mathrm{Zn}$ has affected the properties of the IMC phases normally produced in the joint interface region by: i) slightly increasing the hardness and modulus of $\gamma-\mathrm{Al}_{12} \mathrm{Mg}_{17}$ and $\varepsilon-\mathrm{Al}_{30} \mathrm{Mg}_{23}$, by $5 \%-10 \%$ and; ii) replacing $\beta$ with the $\tau$ phase which has a higher hardness and elastic modulus.
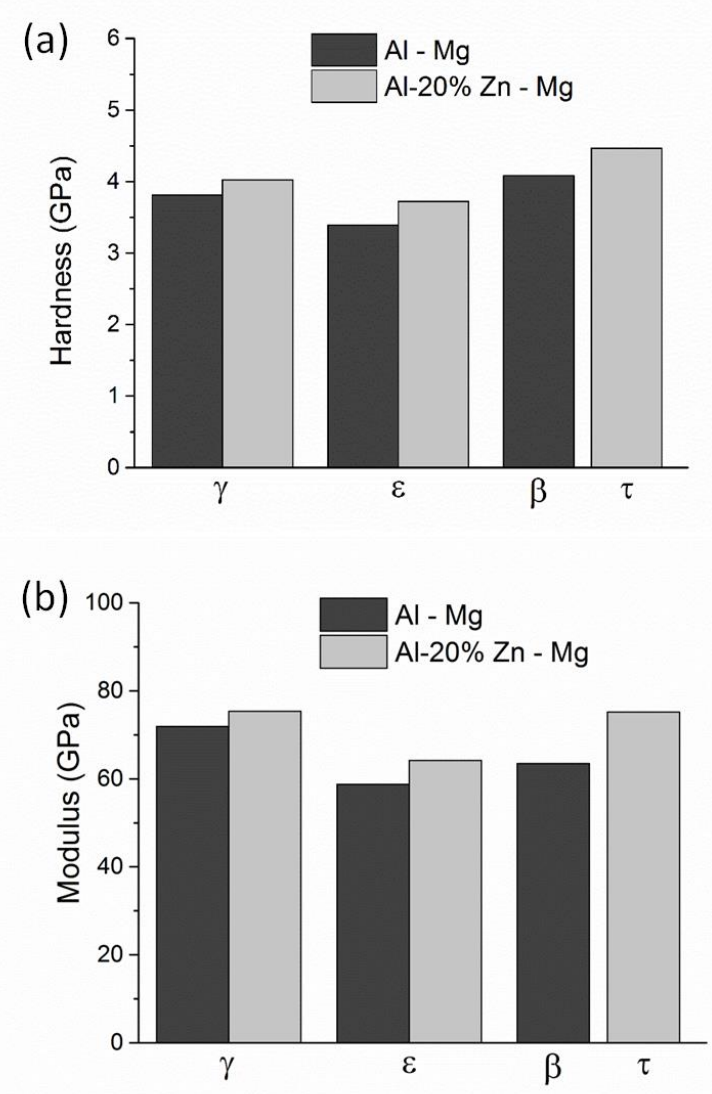

Fig. 6 Mechanical properties of the IMC compounds found in the $\mathrm{Al}-20 \% \mathrm{Zn}-\mathrm{Mg}$ and the $\mathrm{Al}-$ Mg baseline couples, measured by nano-indentation tests; (a) elastic moduli; (b) average hardness. 


\subsection{FSSW}

\section{Interfacial Reaction}

Cross-sections from Refill-FSSWs produced between the Al-20\% $\mathrm{Zn}$ interlayer alloy predicted to be the minimum composition level required to suppress $\beta-\mathrm{Al}_{3} \mathrm{Mg}_{2}$ formation and the $\mathrm{Mg} \mathrm{AZ31}$ alloy, are compared to the baseline AA6111- AZ31 sample in Fig. 7. The welding conditions used were designed to produce minimal plunge into the $\mathrm{Al}$ bottom sheet $(0.1 \mathrm{~mm})$ and the joint interface is still clearly defined in both weld combinations. However, because of its high Zn content, the Al-Zn alloy had a higher hardness than the AA6111 alloy (128 as opposed $87 \mathrm{HV}_{\mathrm{V}}$ ). As a result, the interface region of the $\mathrm{Al}-\mathrm{Zn}$ - Mg joint has experienced less deformation and appears flatter than that in the baseline weld. Due to heterogeneity in the thermal and deformation history across the weld interface $[4,27,35]$ four sites (site A-D) were selected for microstructural characterization (Fig. 8). For each site, the average IMC layer thicknesses were measured and the results are listed in Table 2.

Compared to in the static heat treatment samples, the binary $\varepsilon-\mathrm{Al}_{30} \mathrm{Mg}_{23}$ phase was absent from both sets of FSSW joints, which is not unexpected given that the $\varepsilon$ phase is known to have sluggish kinetics and typically only forms after long annealing times (e.g. tens of hours) [7, 16]. The BSE images in Fig. 8 show that two IMC reaction layers were produced in each weld combination, with uneven thickness. Similar to in the static heat treatment samples, in the $\mathrm{Al}-\mathrm{Mg}$ baseline sample (Fig. 8a-d) the upper layer adjacent to the $\mathrm{Mg}$ side of the interface was identified to be $\gamma-\mathrm{Al}_{12} \mathrm{Mg}_{17}$ and the lower layer the $\beta-\mathrm{Al}_{3} \mathrm{Mg}_{2}$ phase. However, the $\gamma$ phase formed the thicker reaction product $(\sim 4 \mu \mathrm{m})$, while the $\beta-\mathrm{Al}_{3} \mathrm{Mg}_{2}$ phase was thinner, being approximately only $1 \mu \mathrm{m}$ thicker, whereas in the long-term annealing experiments $\beta$ formed the thickest IMC layer. On average, the total IMC layer thickness in the $\mathrm{Al}-\mathrm{Mg}$ sample was therefore about $5 \mu \mathrm{m}$. 

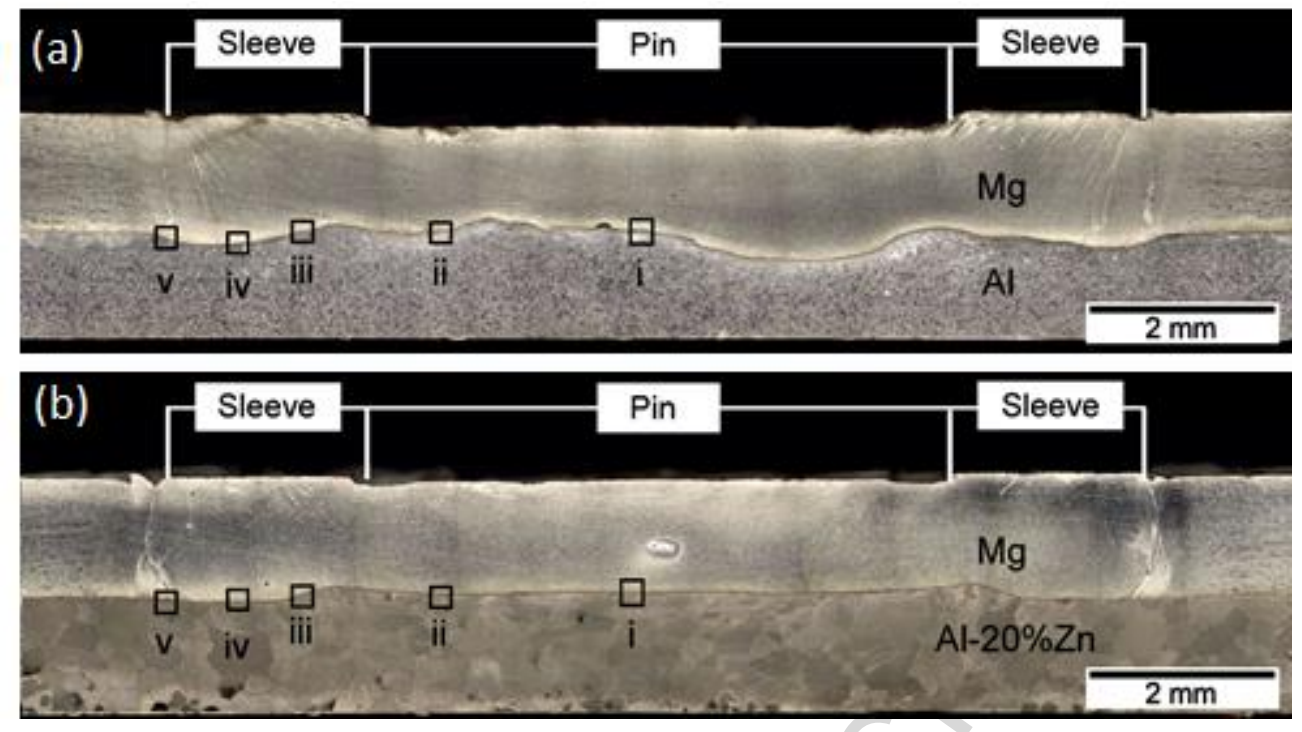

Fig. 7 Full cross sections of the Refill dissimilar $\mathrm{Al}$ - Mg(AZ31) welds produced between; (a) the AA6111 baseline and (b) the Al-20\% Zn inter layer alloy.

Importantly, compared to in the baseline sample, the $\mathrm{Al}-\mathrm{Zn}-\mathrm{Mg}$ welds produced under identical conditions exhibited a dramatic reduction of more than $80 \%$ in the total IMC layer thickness, to less than $1 \mu \mathrm{m}$ (Fig. 8; Table 2). The reaction layers also appeared to be more uniform. The insert images in Fig. 8 (e-h) show the interfacial region at a higher magnification, from which two reaction layers of a similar thickness of about $400 \mathrm{~nm}$ can be observed across the entire weld interface.

Table 2 Average IMC thickness in the Refill weld samples measured at sites A-D, marked in Fig. 7.

\begin{tabular}{ccccc}
\hline & \multicolumn{3}{c}{ Average IMC thickness $(\mu \mathrm{m})$} \\
Material & Site i. & Site ii. & Site iii. & Site iv. \\
\hline $\mathrm{Al}-20 \% \mathrm{Zn}-\mathrm{Mg}$ & 0.83 & 0.82 & 0.76 & 0.60 \\
$\mathrm{Al}-\mathrm{Mg}$ & 5.54 & 4.63 & 4.96 & 6.73 \\
\hline
\end{tabular}



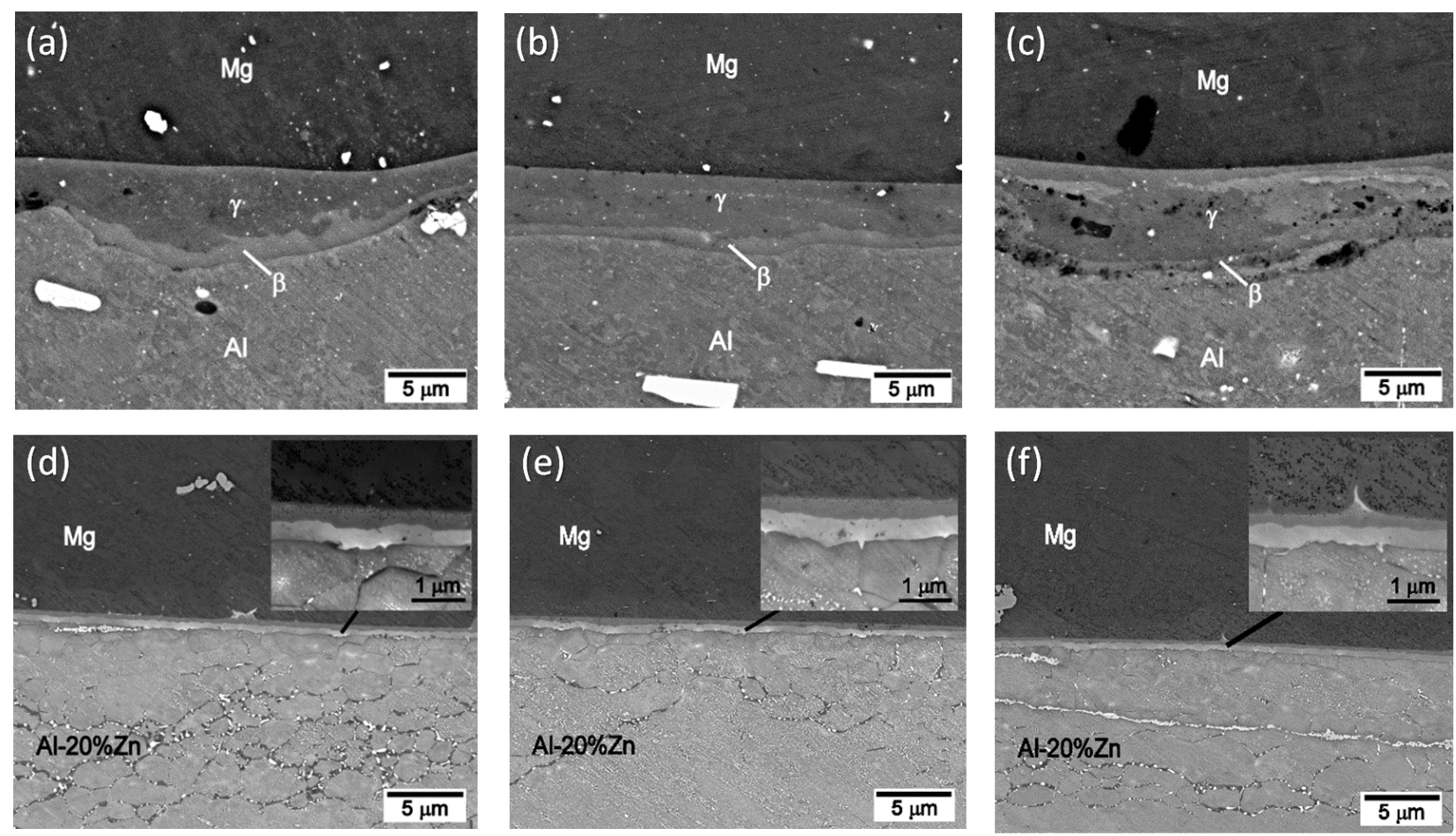

Fig. 8 SEM-BSE micrographs showing the weld interface IMC reaction layer in dissimilar joints produced by Refill-FSSW at sites I, ii \& iv (see Fig 7) in; (a)-(c) the Al-Mg baseline and (d)-(f) the Al-20\% Zn - Mg sample.

TEM analysis was carried out to identify the phases present at the interface in the $\mathrm{Al}-20 \% \mathrm{Zn}-\mathrm{Mg}$ weld. In Fig. 9 two reaction layers are discernible. Diffraction patterns from the layer adjacent to the Al-Zn alloy were again indexed to be from the ternary $\tau-(\mathrm{Al}, \mathrm{Zn})_{49} \mathrm{Mg}_{32}$ phase, and the layer on the $\mathrm{Mg}$ side was consistent with the $\gamma-\mathrm{Al}_{12} \mathrm{Mg}_{17}$ phase. No $\beta-\mathrm{Al}_{3} \mathrm{Mg}_{2}$ was detected at the interface, indicating that the predicted optimum $\mathrm{Zn}$ composition was also effective in preventing this intermetallic phase forming under welding conditions. 


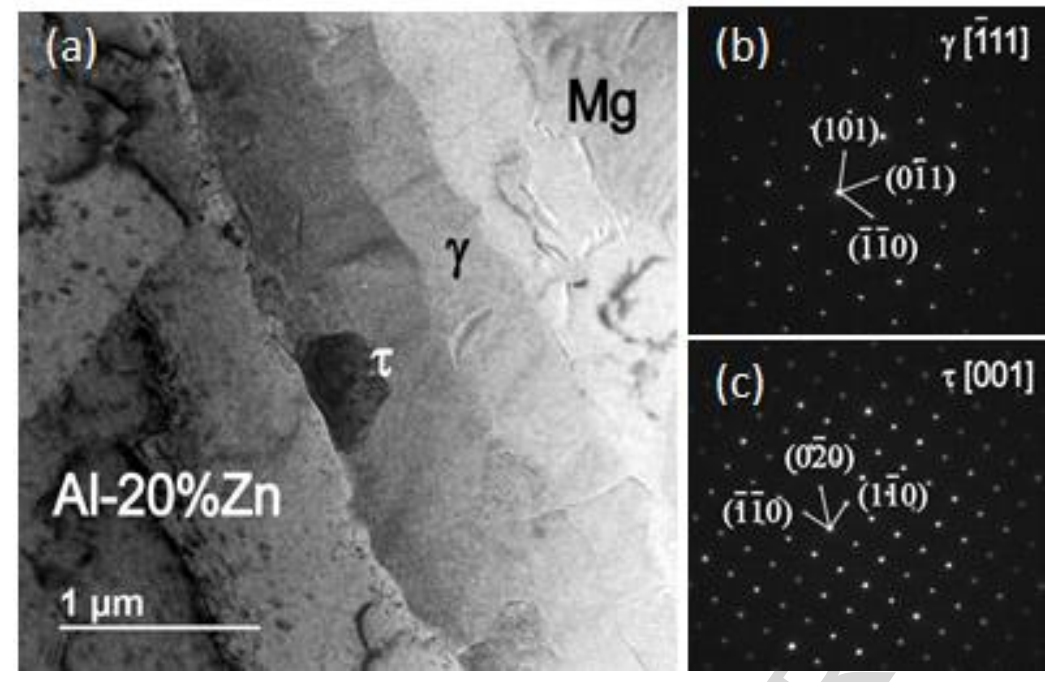

Fig. 9 TEM characterization of the IMC interface layers found in the Refill welded Al-20\% $\mathrm{Zn}-$ Mg sample; (a) the phases of interest; (b) and (c) selected are diffraction patterns from the $\gamma-\mathrm{Al}_{12} \mathrm{Mg}_{17}$ and $\tau-(\mathrm{Al}, \mathrm{Zn})_{49} \mathrm{Mg}_{32}$ layer, respectively.

\section{Weld Interface Temperatures}

In dissimilar welds the interface temperature rise can strongly affect interfacial reactions, both thermodynamically and kinetically $[2,11,12,29]$. While all the welds were prepared with identical conditions, in a friction-welding process coupling between the tool and weld members and the material flow properties at temperature determines the rate of heat generation $[35,36]$. Before coming to firm conclusions with regard to the respective growth rates of IMC phases produced between different alloys, it was thus important to compare the interface temperature rise in each weld sample. Fig. 10 shows examples of typical temperature histories measured from the two dissimilar joint types during welding. The temperature cycles are characteristic of the Refill-FSSW process, when temperature is measured below the sleeve position. Initially, there is a very rapid heating rate during the sleeve plunge phase. This is followed by a peak corresponding to the shoulder plunge dwell and then a decrease as the sleeve is withdrawn and the pin advanced, and a final decrease when the tool is retracted [27, 28]. 


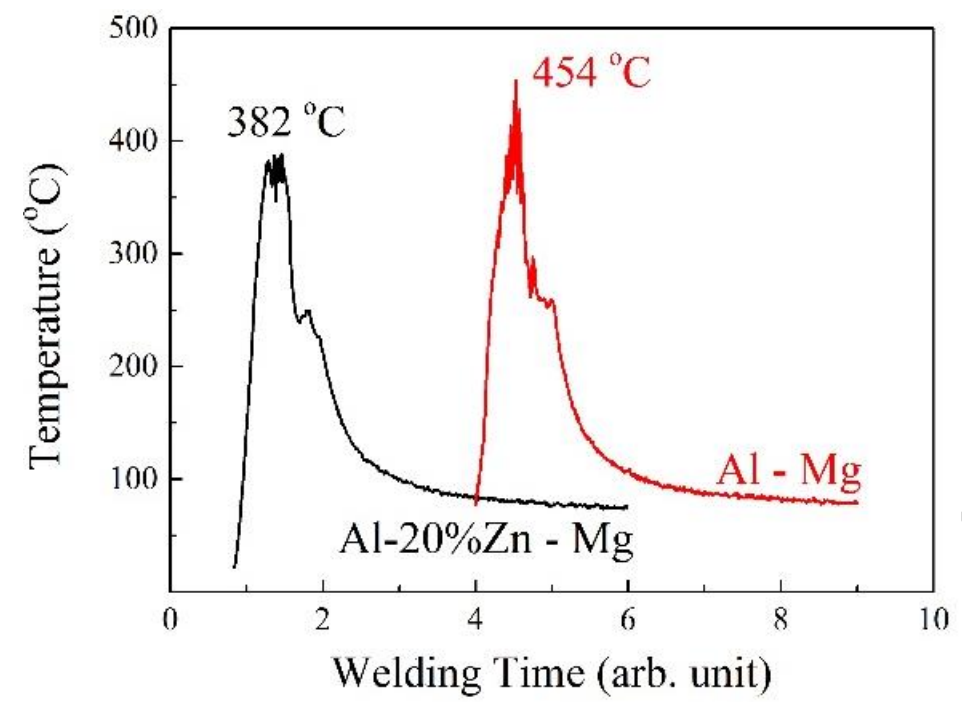

Fig. 10 Typical thermal histories measured under the sleeve at the interface of the Al-20\% $\mathrm{Zn}-\mathrm{Mg}$ and $\mathrm{Al}-\mathrm{Mg}$ Refill ${ }^{\mathrm{TM}}$ weld samples (the curves are off-set for clarity).

The thermocouples were placed at the joint interface directly under the sleeve, where the tool surface velocity is greatest and the most heat is generated $[27,28]$. The peak temperatures recorded at this positon would therefore be expected to be close to the highest temperatures reached at the joint interface. The average peak temperature measured for the Al-20\% $\mathrm{Zn}-\mathrm{Mg}(\mathrm{AZ} 31)$ sample was $385{ }^{\circ} \mathrm{C}$, which is close to $360^{\circ} \mathrm{C}$ - the simulation temperature selected for coating design, but this was significantly lower than that reached in the baseline $\mathrm{Al}(6111)-\mathrm{Mg}(\mathrm{AZ31})$ welds $\left(452{ }^{\circ} \mathrm{C}\right)$.

Local melting is commonly found in friction stir welded $\mathrm{Al}-\mathrm{Mg}$ joints [4-6, 28, 29], especially on the periphery of the tool (such as at site v. in Fig. 7a). In this study, the average peak temperature measured for the $\mathrm{Al}-\mathrm{Mg}$ weld of $452{ }^{\circ} \mathrm{C}$ coincided almost exactly with the lowest temperature at which $\beta-\mathrm{Al}_{3} \mathrm{Mg}_{2}$ liquation initiates in the binary $\mathrm{Al}-\mathrm{Mg}$ system $\left(450{ }^{\circ} \mathrm{C}\right)$, which is the eutectic temperature for the reaction $(\mathrm{Al})+\beta \rightarrow \mathrm{L}$, although the reaction $(\mathrm{Mg})+\gamma \rightarrow \mathrm{L}$ takes place a slightly lower temperature $\left(437^{\circ} \mathrm{C}\right)[15,16]$. SEM investigation in Fig.11a and b, taken at the edge of the weld zone (site $\mathrm{E}$ in Fig. 7a), also shows the $\beta-\mathrm{Al}_{3} \mathrm{Mg}_{2}$ phase to have re-solidified with dendritic morphology within a eutectic matrix. 
In the ternary $\mathrm{Al}-\mathrm{Mg}-\mathrm{Zn}$ system there are several lower melting point reactions which extend down to $338{ }^{\circ} \mathrm{C}(611 \mathrm{~K})$ at the $\mathrm{Al}, \mathrm{Mg}$ rich side of the diagram $((\mathrm{Mg})+\mathrm{T}+\mathrm{MgZn} \rightarrow \mathrm{L})$ [30] but, given only the $\tau-(\mathrm{Al}, \mathrm{Zn})_{49} \mathrm{Mg}_{32}$ and $\gamma-\mathrm{Al}_{12} \mathrm{Mg}_{17}$ phases are present at the interface, with the $\mathrm{Al}-20 \% \mathrm{Zn}-$ $\mathrm{Mg}$ weld melting is more likely to occur at a higher temperature, which is in agreement with the measured maximum temperature rise of $\sim 380{ }^{\circ} \mathrm{C}$. In Fig. 11 c and d, microstructural evidence can also be seen for some eutectic formation at the joint interface in images taken from site v. in Fig. 7, which was the hottest position at the weld interface. It can thus be concluded that during the weld cycle interfacial reaction mainly took place in the solid state, but liquation occurred locally near the edge of the tool sleeve positon in both joints, where different melting temperatures were exceeded and in both cases this restricted the maximum interface temperature reached.
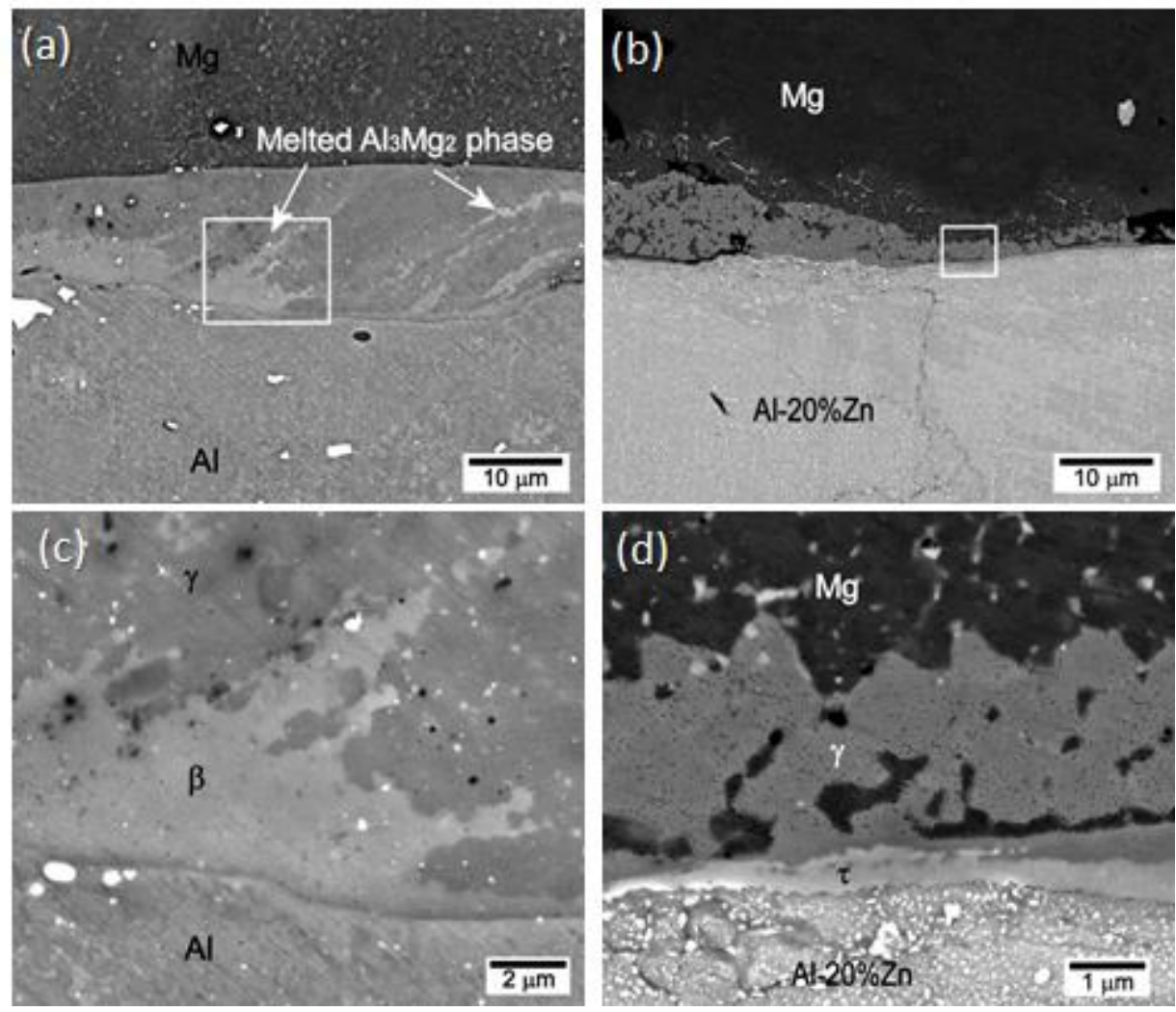

Fig. 11 SEM-BSE micrographs showing evidence of limited eutectic melting found at the edge of the weld zone under the tool sleeve; (a) in the $\mathrm{Al}-\mathrm{Mg}$ weld; (b) the Al-20\% $\mathrm{Zn}-\mathrm{Mg}$ weld; (c) and (d) showing enlarged views from the positions indicated. 


\section{Weld Mechanical Properties}

Fig. 12 compares average lap shear strengths measured for the Al-20\% $\mathrm{Zn}-\mathrm{Mg}$ joints to those of the $\mathrm{Al}-\mathrm{Mg}$ baseline dissimilar and $\mathrm{Mg}-\mathrm{Mg}$ similar welds, prepared under identical conditions. It can be seen that the $\mathrm{Zn}$ containing alloy, which was effective in reducing the thickness of interfacial IMC reaction layer, has been beneficial in improving the strength of the dissimilar welds, although this increase was relatively modest (about $6 \%$ ).

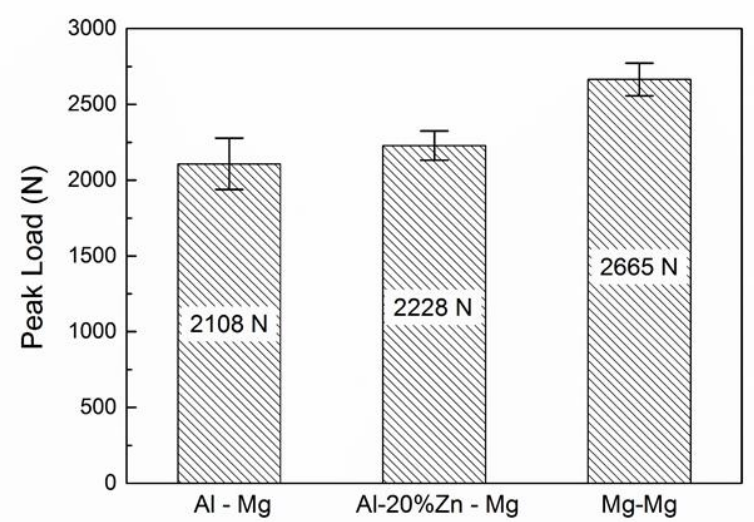

Fig. 12 Comparison of the average lap shear strengths of Refill-FSSWs produced between the dissimilar $\mathrm{Al}-\mathrm{Mg}$ welds and conventional $\mathrm{Mg}-\mathrm{Mg}$ joints, under the same conditions.

The crack propagation behavior, observed by sectioning partially fractured lap shear test samples for the dissimilar welds, is illustrated in Fig. 13. In all joints cracks were found to develop exclusively within the interfacial reaction layer, indicating that the welds' mechanical performance was strongly influenced by intermetallic reaction. However, unlike in the $\mathrm{Al}-\mathrm{Mg}$ baseline sample, in which cracking mainly occurred within the $\beta-\mathrm{Al}_{3} \mathrm{Mg}_{2}$ phase layer (Fig. 13a), in the $\mathrm{Al}-20 \% \mathrm{Zn}-$ $\mathrm{Mg}$ the crack path exclusively followed the $\gamma-\mathrm{Al}_{12} \mathrm{Mg}_{17} / \mathrm{Mg}$ interface and no cracking was seen within the intermetallic layers (Fig. 13b). The fact that the crack path followed the site of eutectic melting, suggests that in this sample a weak interface with the eutectic layer was the major cause of failure, rather than the presence of the interfacial IMC phases. 
Finally, it should be noted that the stress state in a lap 'shear' test is not pure shear and is dependent on the yield strength of the weld members and stress concentration at the weld edge. For example, the test naturally bends the weld out of plane, which creates a tensile component normal to the join line and the degree of 'hooking' [4, 22, 29] will also influence the local stress state where fracture initiates. Both of these effects are material dependent and would be expected to be more complex in a bi-metallic sample. This means that direct comparison of fracture strength results should be considered with caution, although the lap shear tests have provided clear evidence that it is possible to change the fracture mechanism by 'designing' an interlayer material.
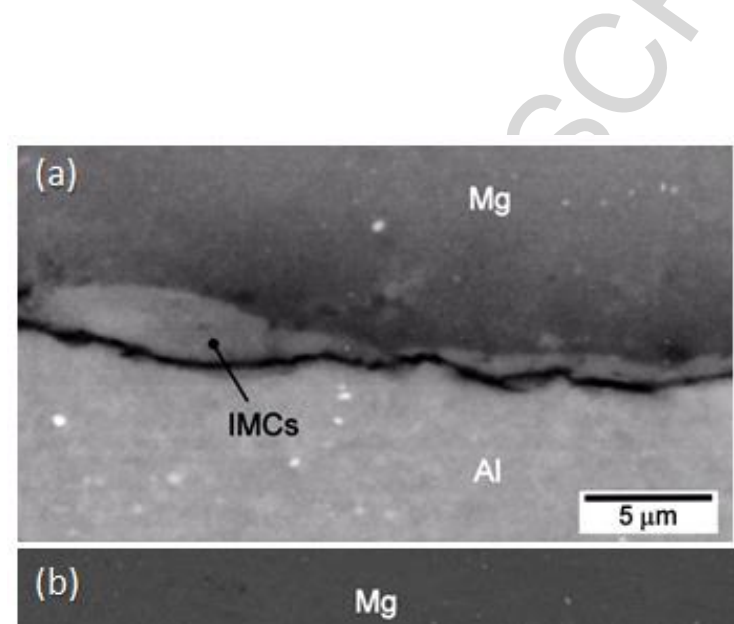

Fig. 13 Crack propagation at the interfacial region of (a) the conventional $\mathrm{Al}-\mathrm{Mg}$ weld and (b) the Al-20\% Zn - Mg dissimilar weld.

\subsection{Coating Design}

In this work a major aim was to validate an efficient method for selecting interlayer alloys that 
could be practically used in friction stir welding and would change the IMC reaction path at the joint interface in $\mathrm{Al}-\mathrm{Mg}$ dissimilar welds. Simplified calculations were thus first performed where an $\mathrm{Al}-\mathrm{Zn}$ to $\mathrm{Mg}$ alloy joint was approximated as a static diffusion couple, without considering the influence of other factors that can be important in the welding process (e.g. temperature variation and deformation / material flow, etc.). By adopting a single phase solid solution model, the problem was further simplified and the composition in the interdiffusion region become a function of only three variables (the composition for the Al-Zn alloy, diffusion distance, and time), which could be conveniently obtained by performing iterations of the diffusion functions. Strictly speaking, this approach is applicable only to the initial stage of interdiffusion, in which the compositional changes are insufficient to induce the formation of any new phases. When IMC phases start to appear, the situation becomes much more complicated as across the interface diffusion becomes affected by many other factors that are not readily obtainable, such as the IMC nucleation behavior, the migration rate of the IMC phase boundaries, as well as the diffusion mechanism and related kinetic parameters (e.g. bulk / grain boundary diffusion), and the grain structure and coarsening rate within each IMC layer $[12,14]$. However, overall the approach adopted was found to give good agreement with the experimental results and successfully predicted the desired interlayer composition. The simplified method adopted here can therefore be viewed as providing a practical first step for interlayer selection in dissimilar welding, by predicting the phases that are thermodynamically expected to from in a given temperature window and alloy combination.

\section{The Effectiveness of the Designed Coating for IMC Control in FSSW}

The selected Al-20 \% Zn coating alloy had two major effects on joint performance; one successfully predicted from thermodynamic considerations that did not work as well as expected, and one that was not anticipated, but proved more significant, related to the interaction between phase equilibrium and the friction welding process, which with hindsight could have equally been readily calculated in advance using the CALPHAD approach. Firstly, in line with the thermodynamic and inter-diffusion predictions, the coating material successfully changed the reaction path at the joint interface and prevented the formation of the undesirable $\beta-\mathrm{Al}_{3} \mathrm{Mg}_{2}$ phase in favor of the $\tau$-(Al,Zn $)_{49} \mathrm{Mg}_{32}$ phase, which could be beneficial for improving the interface strength. However, owing to a lack of prior kinetic data, it was not possible to predict in advance that the ternary $\tau$-phase would have a slightly higher growth rate than the $\beta$ phase it replaced. Although the $\tau$-phase 
was measured to have a higher hardness and elastic modulus than the $\beta$ phase, it has not yet been determined if this translates into a higher fracture toughness. But, given that the toughness of such phases is typically extremely low [7, 19], any improvement in terms of the weld properties would be expected to be marginal relative to the effect of reducing the IMC layer thickness.

Secondly, in a real friction welding situation the temperature at the joint interface was substantially reduced by approximately $60^{\circ}$, when using the interlayer material relative to that recorded with the baseline alloy (AA6111). This decrease in temperature had a more dramatic effect on reducing the IMC reaction layer thickness than changing the reaction path and can be attributed to a reduction in the power dissipated in the welding process, which was limited by a lower liquation temperature at the weld interface. When welding the Al- $\mathrm{Zn}$ alloy, the liquation point was lowered by the addition of $\mathrm{Zn}$, making the edge of the weld zone more prone to melting at a reduced temperature. The lower liquation temperature led to a drop in the maximum weld temperature and hence caused a marked reduction in the IMC growth rate across the majority of the joint interface where melting did not occur, which helped to enhance the weld strength. However, the resultant eutectic layer then became the main cause of weld failure, by providing an easy path for crack propagation, which largely counteracted the potentially positive effects of the coating material in terms of reducing the IMC layer thickness. As a result, only a modest improvement in the welds' mechanical performance was achieved by the application of the Al-Zn coating alloy.

\section{Conclusions}

In this research, a numerical method that combined CALPHAD thermodynamic calculations with diffusion simulations was developed to pre-select the composition for an Al-Zn coating alloy that could supress the formation of the $\beta-\mathrm{Al}_{3} \mathrm{Mg}_{2}$ phase, at the joint interface between $\mathrm{Al}$ and $\mathrm{Mg}$ automotive alloys during dissimilar friction stir spot welding. Although relatively simple, the modelling method used has been shown to be capable of providing a practical first step in interlayer selection in dissimilar welding, by predicting the phases that are thermodynamically expected to form in a given temperature window and alloy combination. 
The modelling results indicated that 20 at. \% was the minimum $\mathrm{Zn}$ concentration required to completely avoid the most rapidly growing $\beta-\mathrm{Al}_{3} \mathrm{Mg}_{2}$ phase. Static interdiffusion experiments validated the modelling results, by confirming that the formation of the $\beta-\mathrm{Al}_{3} \mathrm{Mg}_{2}$ phase was successfully inhibited at the joint interface to be replaced by the ternary $\tau-(\mathrm{Al}, \mathrm{Zn})_{49} \mathrm{Mg}_{32}$ phase, in samples prepared with the Al-20 at. \% Zn and Al-30 at. \% coating alloys. An Al-10 at. Zn\% alloy was also confirmed to be under alloyed, as in the $\mathrm{Al}-10 \% \mathrm{Zn}-\mathrm{Mg}$ samples collaborative columnar growth was observed between the $\mathrm{A} \beta-\mathrm{l}_{3} \mathrm{Mg}_{2}$ and $\tau-(\mathrm{Al}, \mathrm{Zn})_{49} \mathrm{Mg}_{32}$ phases within the IMC layer at the joint interface.

Nano indentation tests suggested that the ternary $\tau$ phase had a higher hardness and Young's modulus than the $\beta$ phase. However, overall under static annealing conditions, the Al-20\% $\mathrm{Zn}$ coating alloys showed little benefit, in terms of reducing the overall thickness of the IMC reaction layer, as the growth rate of the $\tau$-phase was found to be similar to that of the $\beta$ phase it replaced.

Nevertheless, in FSSW of Al to Mg the Al-20\% Zn coating alloy (which had the predicted optimum composition) was found to be highly effective in reducing the extent of interfacial reaction at the joint interface. Welding with an Al-Zn rich coating alloy again replaced the $\beta$ phase with $\tau$-(Al, $\mathrm{Zn})_{49} \mathrm{Mg}_{32}$, but also resulted in a significant reduction in the total thicknesses of the IMC reaction layer, from 4 to $1 \mu \mathrm{m}$. However, this thickness reduction was found to be largely caused by the lower liquation temperature in the Al-Mg-Zn system, which limited the maximum weld temperature, and the resultant eutectic layer produced facilitated failure at the weld interface. As a result, despite the much thinner IMC layer, only a modest increase was seen in the strength of the welds prepared with the coating alloy.

\section{Acknowledgements}

The authors would like to thank the EPSRC programme grant LightForm (EP/R001715/1) for 
funding this research.

\section{References}

[1] J. Hirsh, Materials Transaction, 52 (2011) 818-824.

[2] A. Simar, M-N. Avettand-Fènoël, Sci. Technol. Welding Joining, 22 (2017) 389-403

[3] A. Panteli, J.D. Robson, I. Brough, P.B. Prangnell, Mater. Sci. Eng. A, 556A (2012) 31-42.

[4] U. Suhuddin, V. Fischer, F. Kroeff, J.F. dos Santos, Mater. Sci. Eng. A, 590A (2014) 384-389.

[5] H.M. Rao, J.B. Jordon B. Ghaffari, X. Sub, A.K. Khosrovaneh, M.E. Barkey, W. Yuan, M. Guo, Int. J. of Fatigue, 82 (2016) 737-747.

[6] Z. Liang, G. Qin, H. Ma, F. Yang and Z. Ao, Sci. Technol. Welding Joining, 22 (2017) 363-372.

[7] Y. Wang, P.B. Prangnell, Mater. Characterization, 134 (2017) 84-95.

[8] E.T. Njiokep, M. Salamon, H. Mehrer, Defect Diffusion Forum, 194-199 (2001)1581-1586.

[9] Y. Minamino, T. Yamane, T. Miyake, M. Koizumi, Y. Miyamoto, Mater. Sci. Technol. 2 (1986) 777-783.

[10] Z.F. Li, J. Dong, X.Q. Zeng, C. Lua, W.J. Ding, Z.M. Ren, J. Alloys Compd. 440 (2007)132136.

[11] J.D. Robson, A. Panteli, P.B. Prangnell, Sci. Technol. Welding Joining, 17 (2012) 447-453.

[12] L. Wang, Y. Wang, P. Prangnell, J. Robson, Metall. Mater. Trans. A, 46 (2015) 4106-4114.

[13] H. Springer, A. Kostka, E.J. Payton, D. Raabe, A. Kaysser-Pyzalla, G. Eggel, Acta Mater. 59 (2011) 1586-1600.

[14] L. Xu, J.D. Robson, L. Wang, P.B. Prangnell, Metal. Mater. Trans. A (2017), https://doi.org/10.1007/s11661-017-4352-y.

[15] J. Murray, Bulletin Alloy Phase Diagrams, 3 (1982) 60-74.

[16] H.L. Su, M. Harmelin, P. Donnadieu, C. Baetzner, H.J. Seifert, H.L. Lukas, G. Effenberg, F. Aldinger, J. 
Alloys Compds. 247 (1997) 57-65.

[17] H.L. Su, M. Harmelin, P. Donnadieu, C. Baetzner, H.J. Seifert, H.L. Lukas, G. Effenberg, F. Aldinger, J. Alloys Compnds. 247 (1997) 57-65.

[18] D. Dietrich, D. Nickel, M. Krause, T. Lampke, M. Coleman, V. Randle, J. Mater. Sci. 46 (2011) $357-364$.

[19] P. Venkateswaran, Z. Xu, X. Li, A. Reynolds, J. Mater. Sci., 44 (2009) 4140-4147.

[20] A. Panteli, J. Robson, Y.-C. Chen, P. Prangnell, Metall. Mater. Trans. A, 44 (2013) 5773-5781.

[21] H. Zhang, J. Song, Mater. Lets, 65 (2011) 3292-3294.

[22] R.Z. Xu, D.R. Ni, Q. Yang, C.Z. Liu, Z.Y. Ma, J. Mater. Sci. \& Technol. 32 (2016) 76-88.

[23] L. Zhao, Z. Zhang, Scripta Mater., 58 (2008) 283-286.

[24] L. Liu, L. Zhao, R. Xu, Materials and Design, 30 (2009) 4548-4551.

[25] C. Schilling, and J.D. Santos: US6722556 B2, 2004.

[26] B.M. Al-Zubaidy, Y-C. Chen, and P.B. Prangnell: Assessment of rapid refill FSSW for 6111-T4 aluminium automotive alloys, $14^{\text {th }}$ Int. Frict. Stir Weld. Symp., Beijing, China, TWI. 2014.

[27] B.M. Al-Zubaidy: Material interactions in a novel refill friction stir spot welding approach to joining $\mathrm{Al}-\mathrm{Al}$ and Al-Mg automotive sheets. Ph.D. Thesis, The University of Manchester, Manchester, UK, 2017, pp. 216-39.

[28] U.F.H. Suhuddin, V. Fischer, and J.F. dos Santos, Scr. Mater., 68, (2013) 87-90.

[39] A. Gerlich, P. Su, T. North, Sci. Technol. Welding Joining, 10 (2005) 647-652.

[30] P. Liang, T. Tarfa, J.A. Robinson, S. Wagner, P. Ochin, M.G. Harmelin, H.J. Seifert, H.L. Lukas, F. Aldinger, Thermochimica Acta, 314 (1998) 87-110.

[31] W. Sun, F. Lincoln, K. Sugiyama, K. Hiraga, Mater. Sci. Eng. A, 294-296 (2000) 327-330.

[32] Y. Wang, S. Guan, X. Zeng, W. Ding, Mater. Sci Eng. A, 416 (2006) 109-118.

[33] N. Tang, M. Wang, H. Lou, Y. Zhao, Z. Li, Materials Chemistry and Physics, 116 (2009) 11-15.

[34] N. Popa, B. Willis, Acta Crystallographica, A60 (2004) 318-321.

[35] P. Jedrasiak, H.R. Shercliff, A. Reilly, G.J. McShane, Y.C. Chen, L. Wang, J.D. Robson, and P.B. Prangnell: J. Materials Eng. Perform., 25 (2017) 4089-98. 
[36] S.W. Williams, P.A. Colegrove, H. Shercliff, P. Prangnell, J.D. Robson, P.J. Withers D. Richards, A.

Sullivan, N. Kamp, D .Lohwasser and M. Poad In: 6th Int. Friction Stir Welding Symposium, October, Sauveur, Canada. TWI 2006. 
Highlights

- Thermodynamic calculations and diffusion simulations have been used to estimate the minimum $\mathrm{Zn}$ concentration (20 at.\%) required in an interlayer alloy to change IMC reaction in $\mathrm{Al}-\mathrm{Mg}$ dissimilar welding.

- The selected coating alloy was effective in changing the Al-Mg reaction path by forming the $\tau-(\mathrm{Al}, \mathrm{Zn})_{49} \mathrm{Mg}_{32}$ phase as a substitute for $\beta-\mathrm{Al}_{3} \mathrm{Mg}_{2}$.

- Refill ${ }^{\mathrm{TM}}$ friction stir spot welds produced with the coating alloy exhibited a thinner reaction layer and an increase in lap shear strength. 